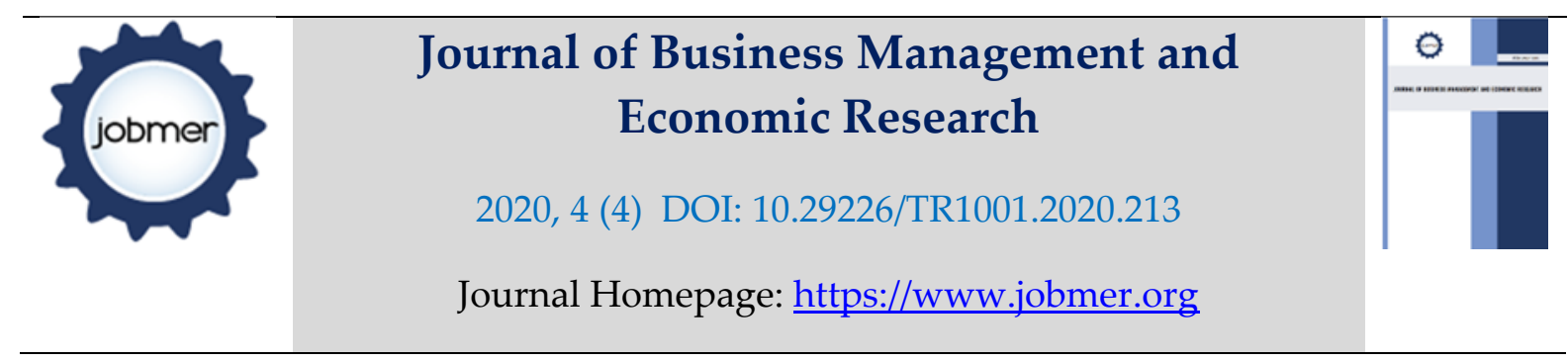

\title{
Does Corporate Governance Mechanisms Matter in Explaining Risk Management? Evidence from Non-Financial Kenyan Listed Firms
}

\author{
Thomas Kiptanui Tarus \\ School of Business and Economics, Moi University, Kenya \\ tarus9116@gmail.com
}

\begin{abstract}
This study attempts to investigate the relationship between corporate governance and risk management in Kenyan listed non-financial firms. The study employed a longitudinal research design and the study's target population was 67 companies. Inclusion-exclusion criteria were used and only 41 listed non-financial firms showed consistency from 2010-2017 giving a total of 328 firm-year observations. Using binary logistic regression analysis, descriptive and inferential statistics were used to analyze data and hypotheses were tested. The regression results revealed that board independence $(\beta=-1.14, \rho<0.05)$ and CEO tenure $(\beta=-0.56, \rho<0.05)$ had a negative and significant effect, while board financial expertise $(\beta=0.56, \rho<0.05)$ had a positive and significant effect on risk management with the predictive power of Pseudo $\mathrm{R}^{2}=28.16$ percent. The study concluded that the independence of board members was detrimental to hedging activities. Long-tenured CEOs were less likely to use financial derivatives tools to hedge risks while financially knowledgeable boards have a better understanding of the sophisticated financial tools involved in risk management mechanisms. The study recommends the reduction of board members' independence and CEO tenure so as to increase hedging activities. It is imperative for the board members to have financial expertise so that they can ascertain risks which are valuable to shareholders.
\end{abstract}

Keywords: Board Independence, CEO Tenure, Board Financial Expertise, Corporate Governance, Risk Management, Agency Theory

\section{Suggested Citation:}

Tarus, T. K. (2020). Does Corporate Governance Mechanisms Matter in Explaining Risk Management? Evidence from Non-Financial Kenyan Listed Firms. Journal of Business Management and Economic Research (JOBMER), Vol: 4, Issue: 4, 318-334. 


\section{Introduction}

Following the 2007-2008 corporate failures, numerous governance initiatives have been suggested to improve corporate governance with significant emphasis on the role of risk management. In this respect, the use of financial derivatives tools (a risk management proxy) to handle risks has become increasingly important owing to enhanced risk complexity and the growth of legislative frameworks among companies (Lechner \& Gatzert, 2018). The establishment of robust risk appetite across all enterprise levels (Gatzert and Martin, 2015) is vital in ensuring proper synchronization and functionality of the risk management system. The holistic perspective on a firm's risk portfolio is anticipated to create value for companies by optimizing their risk-return trade-off and thus creating long term competitive advantage as equated to firms which ascertain, monitor and handle risks individually (Nocco and Stulz, 2006).

Risk management has developed as a key success factor and a priority for companies (Grove and Clouse, 2016) because financial management entails managing risks using a different set of financial instruments. Traditionally the tool of risk management comprised portfolio diversification which was predominant in the previous years. However new tools were developed in the 1970s in the form of financial transactions called derivatives (Grove and Clouse, 2016). Derivatives tools are important elements of the global economy with an estimated market size surpassing $\$ 700$ trillion by 2001 (Bartram et al., 2009). International Swaps Derivatives Association survey of 2009 reports, 94 percent of the world's 500 biggest corporations employ derivatives to manage corporate risks. Therefore, an effective risk management structure is perceived to aid the organization realized its business objectives, enhance its financial reporting as well as safeguarding its reputation. Miccolis \& Shah (2000) pointed out that managers need to manage financial tools that stimulate risk so that they can pursue strategic advantage and opportunities attributed to the risks. During periods of uncertainty and global financial unrest, the function of risk management becomes more essential for company activities (Grote, 2015).

Recuperating from the shocks of corporate failures, representatives and stakeholders are demanding better oversight from organizations particularly from the board of directors for managing and taking responsibility for key risks which firms faced (Maruhun et al., 2018). They further noted that poor corporate governance mechanisms have been identified as the main cause of risk management failure and thus contributed to the global decline of major companies. The impact of the economic crisis had been the wake-up call for most firms when they were unprepared and surprised by the extensions of the debacle (Harner, 2010). The literature has disclosed that the connection between corporate governance and financial risk management aided companies to recognize the risks, mitigate and handle 
those risks in an appropriate way (Zahiruddin \& Norlida, 2013). Management of risk is a crucial mechanism in the company governance framework used as a surveillance instrument to align the principal-agent link so as to reduce the agency issues (Maruhun et al., 2018).

According to Hentschel \& Kothari, (2001) they postulated that over time corporate governance aspects have improved risk management activities such as identifying, measuring and monitoring as well as estimating the efficiency of management controls in managing risks. Nevertheless, despite Kenya's capital market improvement on corporate governance, recent studies in the Kenyan markets have focused on the challenges facing the introduction of derivative tools and reasons why Kenyan firms do not employ derivatives in risk management. According to Murungi et al., (2014), financial derivatives usage among Kenyan firms is low because of managerial skepticism, limited derivative microstructure and limited knowledge on the availability of derivative instruments. Other studies by (Kintu and Ngugi, 2013; Livingstone and Ngugi, 2019) report that Kenyan listed firms exercise a variety of derivative instruments to manage financial risks. Despite research in advanced nations (Bartram et al., 2009; Allayannis et al., 2012; Asghar, 2018), the impact of corporate governance and financial risk management in the Kenyan context has not been adequately documented. To fill this gap and contribute to the body of knowledge, this research attempted to explore the effect of corporate governance attributes on risk management in Kenyan non-financial listed firms.

\subsection{Theoretical Framework}

The Corporate Governance framework according to Fama and Jensen, (1983) has its roots in agency theory derived from the idea of separating ownership and control. In this regard, the theory, therefore, contracts with the resolution of problems occurring between the principal and the agent. In most cases, agents are delegated to act in the best interest of the principal, but occasionally they may fail and be concerned with advancing their individual interests resulting in sometimes denoted agency conflict as the agency problem. To minimize this agency conflict (Jensen and Meckling, 1976), a contract is commonly executed between the principal and the agent. The focus of agency theory on the relationship between the principal and agent has created uncertainty owing to numerous information asymmetries (Deegan, 2004). This implies that the separation of ownership from running the firm can lead to managers taking action that may not maximize shareholders' wealth due to their firm-specific knowledge and know-how which may benefit them and not the shareholders thus monitoring mechanism is intended to protect the owners' interest (Jensen \& Meckling, 1976).

The agency problem of risk management occurs when the principal and the agent have different views on the amount of residual risk to be borne by the entity. According to Smith and Stulz (1985), agents 
will incline to be more risk-averse than the shareholders of the company because a bigger portion of their assets together with their human capital will be connected to the company's accomplishment and continuing existence. Given their command over working strategies, executives have the authority to set the level of risk that maximizes their own usefulness in relation to the level that maximizes shareholder value (Jankensgård, 2019). The theory also clarifies a probable discrepancy between owners, managers and debt holders due to asymmetries in income distribution, which can result in the business taking too much danger (Mayers and Smith, 1987). Agency theory subsequently shows that hedging policies have a significant impact on shareholder value (Fite and Pfleiderer, 1995). Finally, agency theory delivers strong support on hedging as a reaction to the divergence between managerial incentives and shareholders' concerns. This basic principal-agent model can also create information asymmetry, which allows managers to withhold important information to maximize personal interests (Godfrey et al., 2003).

\section{Literature Review}

\subsection{Board independence and risk management}

Agency theory advocates claim that a board with a substantial amount of non-executive directors has a better chance to operate in the best interests of shareholders and improving risk management through efficient supervision of management functions (Klein, 2002). The independence of the board relates to the ratio of non-executive directors to the total number of executives on the board (Reddy et al., 2008). The argument about the need for non-executive directors is grounded on agency theory where shareholders have no control over the company's day-to-day operations (Mizruchi, \& Stearns, 1988; Hillman and Dalziel, 2003) while executives are seen to possess the firm-specific understanding and managerial skills. A potential conflict of interest requires monitoring procedures aimed at safeguarding the interests of the shareholder owners of the company (Jensen and Meckling, 1976). Greater representation of autonomous managers on the board enhances the level of control and enables the board to conduct its strategic tasks more efficiently (Coles et al., 2001).

Previous studies present mixed evidence on how board independence affects firm risk. The study by Pathan (2009) discovered that powerful boards have a positive and significant impact on firm risk. In addition, Borokhovich et al., 2004 discovered a significant and positive connection in their research between the number of derivatives used by corporations and the percentage of external directors on the board. More results by Tai et al., (2014) indicated that the percentage of autonomous managers was significantly and positively linked to the hedging operations of the firm among non-financial companies. However, Brick and Chidambaran (2008) report a negative association between board 
independence and firm combined hedging. In line with their results, Osuoha and Osuoha (2015) discovered that board independence had a negative and significant impact on the relationship between corporate governance and derivatives utilization. Marsden and Prevost (2005) pointed out that companies with a greater proportion of autonomous managers on the board tend to reduce derivatives used as a means of risk management.

Some studies found that board independence is insignificantly related to derivative utilization in risk management (Ho et al., 2013). According to the research by Dionne and Triki (2013), they discovered that the percentage of autonomous managers on the board has no significant effect on the decision to hedge in their study. Moreover, Shiu et al., (2009) also discovered that the proportion of autonomous outside executives on the board is insignificantly linked to risk management. Thus, based on this inconclusive and absence of results on how the presence of non-executive members in the board affects risk management or rather the utilization of financial derivatives, this research hypothesized that;

$\mathrm{H}_{1:}$ Board independence has no significant effect on risk management

\subsection{CEO tenure and risk management}

Previous studies by (Payne et al., 2009; Vafeas, 2003) highlighted the importance of the tenure of CEOs who expressed that a long-term tenure increases the performance of the board as it is linked with higher expertise, dedication, and understanding about the enterprise and its company environment. In the context of corporate governance, $\mathrm{CEO}$ tenure refers to the number of years that the $\mathrm{CEO}$ has been in the company (Souder et al., 2012). The findings by Lewellyn \& Muller-Kahle (2012) revealed that CEO tenure was statistically significant and negatively related to the firm's decision to perform risk management actions. According to Campbell et al., (2011) on their study found that tenured CEO has a negative and significantly associated with risk management. In another study by Chen and Zheng (2014), they found that an entrenched CEO may enjoy the benefits of more control hence they might become less motivated to make risky decisions

In the same line, Tufano (1996) argued that newly appointed CEOs were more motivated to implement risk management procedures based on the use of derivatives. Results based on 48 companies in his study disclosed that the length of CEO tenure was significantly and positively associated with the application of risk management. According to $\mathrm{Xu}$ (2011), the results showed that CEO tenure is positively associated with capital expenditure and research and development expenditure, and CEOs do not perform better when they have a shorter horizon and an influence on investment. Brennan and Conroy (2013) found that the longer-tenured CEO the more likely a CEO is to consider risky alternatives 
instruments for hedging purposes. Belkhir (2006) indicated that a manager may be more conservative behavior and want to protect his job hence CEO would be inherently cautious based on individual human capital in the company. Moreover, Bebchuk and Spamann (2009) suggested that CEOs playing the dominant roles and they tend to make more risk-averse decisions. Pathan, (2009) provides that a CEO has more power to influence any decisions of the board and take the lower risk because managers have un-diversifiable wealth including human capital and comparatively fixed salary. However, Dionne and Triki (2013) argue that CEO tenure is insignificant related to hedging decisions when using the delta percentage as the hedge variable in the gold mining industry. According to Boubaker et al., (2010), the likelihood of derivatives usage decreases with the number of years spent by the CEO in the firm which is negatively and statistically insignificant. Malmendier et al., (2011) found an insignificant result for the relationship between CEO tenure and risk management.

$H_{2}$ : CEO Tenure has no significant effect on risk management

\subsection{Board financial expertise and risk management}

Following the latest wave of accounting scandals, regulators have stressed the need for more financial experts on boards arguing that they will need to have stronger board supervision and serve the interests of shareholders (Güner et al., 2008). Corporations that lack the financial expertise of board members played a major role in the crisis period (Kirkpatrick, 2009). Financial experts must have the ability to oversee accounting controls and the financial reporting of the firm, thus preventing possible reporting failures, litigation, and scrutiny from policymakers. Those directors specializing in different industries monitor and give advice to firms in those sectors because their financial expertise gives them an edge (Güner et al., 2008). In addition, Fama and Jensen (1983) indicated that since the board was mandated to oversee the organization, they were needed to have the understanding that would enable them to execute their responsibilities perfectly. To monitor the process of financial reporting, the directors must have accounting knowledge, in order to control manipulation and to make information more transparent (Yunos et al., 2012).

Financial knowledge is crucial to comprehend the company's complicated operations and the risks connected with the company's policies, but sometimes company boards lacked sufficient financial expertise to identify and control exposures to risk (Srivastav \& Hagendorff, 2016). When there is a shortfall of knowledge, many board members remain silent to save face, which makes them ineffective. In reality, boards of members do often lack in-depth know-how in auditing, risk management and communication (Hilb, 2005). Among a broad spectrum of abilities that managers may have, Chhaochharia and Grinstein (2007) proposed that financial literacy is crucial in any board to work 
efficiently. According to Harris \& Raviv (2008), they indicated that board financial experts have reduced expenses in obtaining data about the complexity and related risks of certain financial operations and are therefore better prepared to track senior management effectively. They also observed that a more financially knowledgeable board can acknowledge risks that are unsound for the firm's economic stability and advise senior executives to prevent such risks. Badolato et al., (2014) report that financial expertise is associated with less usage of financial derivative and better internal control. With regard to the financial competence of the board, the results did not show any important connection between board competence and firm risk (McNulty et al., 2012).

Financial experience among autonomous managers may encourage senior management to use financial derivative tools to hedge against future uncertainties (Acharya et al., 2010). Similarly, Datta et al., (2009) confirmed that board professional experience is a key determinant of boards' ability to make firm strategic decisions regarding hedging mechanisms. However, financial experts may affect firm policies beyond more accurate disclosure and better performance of the audit committee (Krishnan, 2005) and thus managers spend a substantial part of their time advising rather than supervising (Adams \& Ferreira, 2007). Financial board specialists can identify risks that are more useful to shareholders in ordinary times and stimulate management to take on those risks. The results are in conformity with that of Dionne and Triki, (2013) which established that having directors with a university education on the board is an important determinant of the hedging level.

$H_{3}$ : Board financial expertise has no significant effect on risk management

\section{Research Methodology}

According to International Accounting Standards (IAS) 32 and 39, listed firms must disclose their usage of risk management tools in their financial statements. In this regard, a longitudinal research design was used and the data were collected from audited financial statements of non-financial firms from January 2010 to December 2017. The target population of the study was 67 listed firms in Nairobi Securities Exchange as of 31 December 2017. Based on the inclusion-exclusion criteria, a total of 17 financial firms including banks and insurance companies were excluded from the study. Another 7 investment companies were also excluded because they invest in other firms listed at the securities exchange and their performance and operation activities are highly correlated with other firms. Data for two firms were missing thus remaining with 41 listed non-financial firms that fit the requirements of the study. The final sample comprised 41 non-financial listed firms and 328 firm-year observations. 
The study used a binary variable as the dependent variable, one for financial derivative users and zero for non-users as a tool for risk management. The ordinary least square technique can no longer generate the best linear unbiased estimator when a dependent variable is binary. In this situation, a non-linear binary variable adopts the maximum likelihood (ML) estimation technique which requires an assumption about probability distribution like logistic function. The binary logistic regression model applies in the case where the dependent variable is binary and the predictor variables are a mix of a categorical and continuous variable and the data not normally distributed (Hosmer and Lemeshow, 2013).

The study proceeds towards testing the proposed hypotheses where the researcher analyzed the influence of board independence, CEO tenure and board financial expertise that may have an impact on risk management using binary logistic regression. The effect of firm size and firm performance was controlled whose impact on risk management is evidenced in the prior literature. Following the work of (Fok et al., 1997; Géczy et al., 1997; Allayannis and Ofek, 2001 and Purnanandam, 2008), the study used logistic regression analysis to examine the effect of corporate governance attributes on risk management and econometrically, binary logistic regression estimates a multiple linear regression function defined as;

$$
\text { logit }=\beta_{0 i t}+\mathrm{C}+\beta_{1} X_{1 i t}+\beta_{2} X_{2 i t}+\beta_{3} X_{3 i t}+\varepsilon_{i t}
$$

Where; $C=$ Control variable (firm size and firm performance), $X_{1}=$ Board independence, $X_{2}=C E O$ Tenure, $X_{3}=$ Board financial expertise, $\beta_{0}=$ Constant and $\beta_{1}-\beta_{3}=$ coefficient of estimates, logit $=$ is the probability of using derivatives as a measure of risk management, $\varepsilon_{i t}=$ error term. 


\subsection{Summary of Variables}

Table 1: Measurement of Variables

\begin{tabular}{|c|c|c|}
\hline Variables & Measure & Empirical Studies \\
\hline \multicolumn{3}{|l|}{ Dependent Variable } \\
\hline Risk Management & $\begin{array}{l}\text { Dummy variables } 1 \text { for financial } \\
\text { derivative users and } 0 \text { for non-users }\end{array}$ & $\begin{array}{l}\text { Géczy et al., 1997; } \\
\text { Purnanandam, } 2008\end{array}$ \\
\hline \multicolumn{3}{|l|}{ Independent Variable } \\
\hline Board Independence & $\begin{array}{l}\text { The number of non-executive directors } \\
\text { divided by the total number of directors } \\
\text { on the board. }\end{array}$ & $\begin{array}{l}\text { Ferreira \& Kirchmaier, } \\
\text { (2013) }\end{array}$ \\
\hline CEO Tenure & $\begin{array}{l}\text { The number of years the CEO has been } \\
\text { in the company. }\end{array}$ & Souder et al ., (2012) \\
\hline Board Financial Expertise & $\begin{array}{l}\text { The number of board members with } \\
\text { financial experience. }\end{array}$ & $\begin{array}{l}\text { Minton et al., (2014) } \\
\text { Aebi et al., (2012) }\end{array}$ \\
\hline \multicolumn{3}{|l|}{ Control Variable } \\
\hline Firm Size & Natural log of total assets. & Laeven et al., (2014) \\
\hline Firm Performance & Measured as return on assets & Chen et al., (2005) \\
\hline
\end{tabular}

\section{Findings}

The section presents data analysis, presentation, and interpretation of the findings and discussions of the results.

\subsection{Descriptive Statistics}

The statistical summary for risk management, board independence, CEO tenure, board financial expertise, firm size, and firm performance are presented in Table 2. Findings showed that non-financial listed firms had board independence with a $(\mathrm{Mean}=0.659, \mathrm{SD}=0.20$, Skewness $=0.059$ and Kurtosis $=$ 3.149) implying that the proportion of non-executive directors to the total number of directors on the board on average was at 65.9 percent. A review of CEOs tenure which is indicated by the number of years the CEO has been in the company revealed that CEOs have been in the company between a minimum of 2 years and a maximum of 10 years $($ mean $=4.554$ SD $=2.212$, Skewness $=0.072$ and Kurtosis $=1.947)$. This implies that on average the CEOs have been in the company for four years.

Statistical results of board members with financial expertise revealed that (mean $=1.198, \mathrm{SD}=1.228$, Skewness $=0.714$ and Kurtosis $=2.439)$ implying that members with financial expertise are mandated by the shareholders to oversight the complex operations of the firm and the risks associated with the firm's so as to serve their interests of value maximization. More findings revealed that risk management which is a practice of creating economic value in a firm by using financial instruments to manage firm 
risk, exposures and hedge against uncertainties was at a (mean $=0.488, \mathrm{SD}=0.501$, skewness $=0.049$ and kurtosis $=1.002$ ). Statistical results suggest that 48.8 percent of firms have adopted financial derivatives instruments as risk management tools, implying that there is relatively low usage of the financial derivative by non-financial listed firms in Kenya.

Table 2. Descriptive Results of Study Variables

\begin{tabular}{lccccccc}
\hline Stats & Obs & Min & Max & Mean & Sd & Skewness & Kurtosis \\
\hline Risk Management & 328 & 0.00 & 1 & 0.49 & .50 & 0.05 & 1.00 \\
Board Independence & 328 & 0.07 & 1.5 & 0.66 & .20 & -0.06 & 3.15 \\
CEO Tenure & 328 & 2.00 & 10 & 4.55 & 2.21 & 0.07 & 1.95 \\
Board Financial Expertise & 328 & 0.00 & 4 & 1.20 & 1.23 & 0.71 & 2.44 \\
Firm Size & 328 & 8.25 & 11.28 & 9.68 & .61 & 0.07 & 3.16 \\
Firm Performance & 328 & -1.04 & 0.34 & -0.02 & .19 & -1.96 & 9.48 \\
\hline
\end{tabular}

Source: The author

\subsection{Hypothesis testing}

The hypotheses were tested using a random effect model. As suggested by Kohler and Kreuter (2009), the random effect estimator model handles better models that contain time-invariant variables which are commonly omitted by the fixed-effects model. The statistical findings revealed by the logistic regression model showed Pseudo $R^{2}=0.2816$ implying that approximately 28.16 percent of the variation in the output can be explained by the predictor variables in the model. The contribution was statistically significant at $\mathrm{p}<0.05$ level of confidence.

Hypothesis one $\left(\mathrm{H}_{1}\right)$ stated that Board independence had no significant effect on risk management among listed non-financial firms. Findings in Table 3 showed that board independence had coefficients of the estimate which was negative and statistically significant based on $(\beta=-1.14, \mathrm{p}<0.05)$ values. This suggested that there was up to -1.14 unit decline in financial risk management for each unit increase in board independence. The results are consistent with the findings of Osuoha and Osuoha (2015) who found that board independence had a negative and significant effect on the relationship between corporate governance and derivatives usage.

The second $\left(\mathrm{H}_{2}\right)$ hypothesis stated that CEO Tenure had no significant effect on risk management among listed non-financial firms. Further, the findings revealed that $\mathrm{CEO}$ tenure had coefficients of the estimate which was significant and negative based on $(\beta=-0.56, p<0.05)$ values. As such, the longer CEOs serve in the firm, the more the decline in risk management. The results conform to the findings of Campbell et al., (2011) on the association between CEO tenure and derivatives and they found that CEO tenure was significant and negatively related to risk management. 
The third $\left(\mathrm{H}_{3}\right)$ hypothesis of the study stated that board financial expertise had no significant effect on risk management among listed non-financial firms. The statistical findings revealed that board financial expertise had a positive and significant effect on risk management centered on the $(\beta=0.56, p<0.05)$ values. The implication is that an increase in the board's financial expertise brings about better management of risk using derivative tools. The findings are in line with that of Harris \& Raviv, (2008) which established that a more financially knowledgeable board recognizes risks that are unsound for the financial stability of the firm and advise senior managers to avoid such risks.

The goodness of fit tests helps to decide whether the model is correctly fit which is revealed by the Hosmer-Lemeshow goodness of fit results in Table 3. According to Allison, (2014), when the $p$-value is less than 0.05 , then the model is rejected and if the $p$-value greater than 0.05 , then the model passes the test and thus the model is said to be fit. The Hosmer- Lemeshow test yielded Pearson chi ${ }^{2}$ of 125.36 which has a probability of 0.5741 which is more than 0.05 hence implying that the model fits well.

Table 3. Logistic Regression Analysis

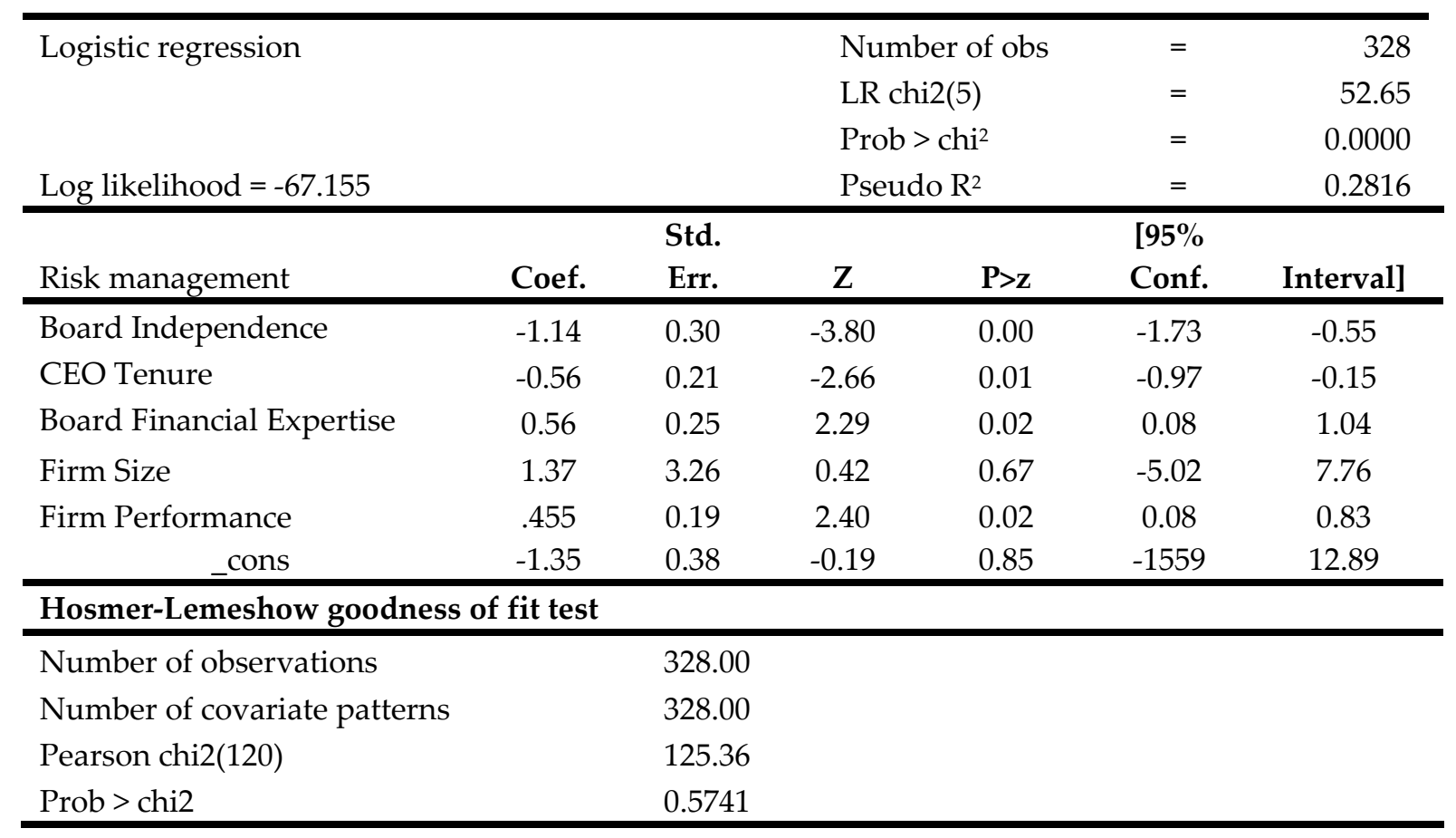

Source: The author

\section{Conclusion and Recommendation}

Board independence elicited a negative and significant effect on risk management. The results revealed that an increase in the proportion of non-executive was detrimental to hedging activities. This is so because non-executive directors have a tendency to diversify their investment in more than one firm 
hence, they are unlikely to be at the forefront in the use of financial derivative instruments to manage risks. The literature does not reach a clear consensus on the impact of board independence on risk management. However, the research is opposite to the argument that hedging increases with outside directors. To enhance the use of financial risk management, there is a need for the independent members of the board to have a minimum level of financial knowledge (education, experience, and accounting) to monitor risk management activities.

The statistical findings revealed that CEO tenure is linked with a decline in risk management. The implication is that long-tenured CEOs are less likely to use financial derivatives to manage risks since they tend to be less receptive to new business ideas that require hedging activities. It implies that an increase in CEO tenure means a reduction in hedging activities. It is therefore important for CEOs overseeing risk management to understand that the utilization of derivatives instruments increases shareholders' value as well as their own incentives. Also, it is essential to appoint new CEOs once the term of the existing ones expires since newly appointed CEOs are more likely to consider risky alternatives and are more receptive to new business ideas that enhance firm value.

Finally, board financial expertise enhances the risk management of non-financial firms. The findings suggest that members of a board that are financially knowledgeable have a better understanding of the sophisticated financial tools involved in risk management activities hence they engage more actively in hedging the firm's exposure to risk and to enhance its shareholder's value. Board financial expertise is essential to enabling risk management and therefore it is vital that board members have financial experience to identify risks that are more useful to shareholders in ordinary times and promote management to take on those risks. Moreover, all non-financial firms must have at least one independent qualified financial expert sitting on the board to help the firm use sophisticated financial instruments for hedging.

\subsection{Recommendation}

\subsubsection{Managerial and policy implication}

The study results have important implications for practicing financial managers. The results will form the basis for the understanding of risk management through the use of financial derivative instruments for hedging against exposures and thus will be helpful to financial managers when making risk management decisions. This is in line with Asghar et al., (2018) who found that corporate governance within a firm encourages managers to use derivative instruments as risk management tools along with investment, financial, and operational strategies for the best interests of the business and its 
shareholders. This study provides policy guidelines for listed firms in Kenya that aim to make optimal use of derivative instruments for reducing interest rates, foreign exchange rates, commodity prices, and equity price exposures. The study also recommends that policymakers must develop a well-established derivative market in Kenya to create awareness of derivatives' usage and to facilitate firms that have high foreign transaction can get benefit by optimally utilizing hedging techniques. As a result, it will not only facilitate the firms to achieve their primary goal of shareholders' wealth maximization but may enhance economic growth.

\subsubsection{Theoretical implication}

The research extends the literature on risk management by employing financial derivatives instruments. This study is among the few that provided insights into a comprehensive set of corporate governance attributes such as board independence, CEO tenure, and board financial expertise. The study also adds to the strand of corporate governance literature by extending the current literature on corporate governance and risk management activities. Though this area has been vastly researched in the financial sector, there is a dearth of such studies in non-financial firms. The research makes a contribution in this area and is the first few studies to document the hedging behavior of firms on corporate governance attributes, and financial risk management among listed non-financial in Kenya. Further research is needed to explore the roles of directors' knowledge and experience in the processes of risk management. While this study only examined internal governance mechanisms, it is possible that external governance factors not explored may have an effect on risk management. This points to the need for future researchers to explore the effect of external corporate governance factors.

\section{References}

Acharya, Viral V., Christian Brownlees, Robert Engle, Farhang Farazmand, and Matthew Richardson (2010). “Measuring Systemic Risk." In Regulating Wall Street, 85-119. Hoboken, NJ: John Wiley and Sons, Inc

Adams, R. B., \& Ferreira, D. (2007). A theory of friendly boards. The journal of finance, 62(1), 217-250.

Aebi, V., Sabato, G., \& Schmid, M. (2012). Risk management, corporate governance, and bank performance in the financial crisis. Journal of Banking \& Finance, 36(12), 3213-3226.

Allayannis, G., Lel, U., \& Miller, D.P. (2012). The use of Foreign Currency Derivatives, Corporate Governance, and Firm Value around the World. Journal of International Economics, 87(1), 6579. 
Allison, P. D. (2014, March). Measures of fit for logistic regression. In Proceedings of the SAS Global Forum 2014 Conference 1-13.

Asghar Butt, A., Nazir, M., Arshad, H., \& Shahzad, A. (2018). Corporate Derivatives and Ownership Concentration: Empirical Evidence of Non-Financial Firms Listed on Pakistan Stock Exchange. Journal of Risk and Financial Management, 11(3), 33.

Badolato, P. G., Donelson, D. C., \& Ege, M. (2014). Audit committee financial expertise and earnings management: The role of status. Journal of Accounting and Economics, 58(2-3), 208-230

Bartram, S. M., Brown, G. W., \& Fehle, F. R. (2009). International evidence on financial derivatives usage. Financial management, 38(1), 185-206.

Bebchuk, L. A., \& Spamann, H. (2009). Regulating bankers' pay. Geo. lJ, 98, 247.

Belkhir M. (2006), Board Structure, Ownership Structure and Firm Performance: Evidence from Banking, EFMA 2005 Meeting.

Borokhovich, K. A., Brunarski, K. R., Crutchley, C. E., \& Simkins, B. J. (2004). Board composition and corporate use of interest rate derivatives. Journal of Financial Research, 27(2), 199-216.

Boubaker, S., Mefteh, S., \& Shaikh, J. M. (2010). Does ownership structure matter in explaining derivatives' use policy in French listed firms. International Journal of Managerial and Financial Accounting, 2(2), 196-212.

Brennan, N. M., \& Conroy, J. P. (2013). Executive hubris: The case of a bank CEO. Accounting, Auditing E Accountability Journal, 26(2), 172-195.

Brick, I. E., \& Chidambaran, N. K. (2008). Board monitoring, firm risk, and external regulation. Journal of Regulatory Economics, 33(1), 87-116.

Campbell, T. C., Gallmeyer, M., Johnson, S. A., Rutherford, J., \& Stanley, B. W. (2011). CEO optimism and forced turnover. Journal of Financial Economics, 101(3), 695-712.

Chen, D., \& Zheng, Y. (2014). CEO tenure and risk-taking. Global Business and Finance Review, 19(1), 127.

Chen, Z., Cheung, Y. L., Stouraitis, A., \& Wong, A. W. (2005). Ownership concentration, firm performance, and dividend policy in Hong Kong. Pacific-Basin Finance Journal, 13(4), 431449 .

Chhaochharia, V., \& Grinstein, Y. (2007). The changing structure of US corporate boards: 1997-2003. Corporate Governance: An International Review, 15(6), 1215-1223.

Coles, J. W., McWilliams, V. B., \& Sen, N. (2001). An examination of the relationship of governance mechanisms to performance. Journal of Management, 27(1), 23-50.

Datta, D. K., Musteen, M., \& Herrmann, P. (2009). Board characteristics, managerial incentives, and the choice between foreign acquisitions and international joint ventures. Journal of Management, 35(4), 928-953.

Deegan, C. (2004). Environmental disclosures and share prices-a discussion about efforts to study this relationship. In Accounting Forum 28(1), 87-97.

Dionne, G., \& Triki, T. (2013): On Risk Management Determinants: What Really Matters? European Journal of Finance, 19(2), 145-164.

Fama, E. F., \& Jensen, M. C. (1983). Separation of ownership and control. The journal of law and Economics, 26(2), 301-325. 
Ferreira, D., \& Kirchmaier, T. (2013). Corporate boards in Europe: size, independence and gender diversity. Boards and Shareholders in European Listed Companies: Facts, Context and Post-Crisis Reforms, 191-224.

Fite, D., \& Pfleiderer, P. (1995). Should firms use derivatives to manage risk? Problems and solutions, Risk management 61-76.

Fok, R. C., Carroll, C., \& Chiou, M. C. (1997). Determinants of corporate hedging and derivatives: A revisit. Journal of Economics and Business, 49(6), 569-585.

Gatzert, N., \& Martin, M. (2015). Determinants and value of enterprise risk management: empirical evidence from the literature. Risk Management and Insurance Review, 18(1), 29-53.

Géczy, C., Minton, B. A., \& Schrand, C. (1997). Why firms use currency derivatives. The Journal of Finance, 52(4), 1323-1354.

Godfrey, J., Mather, P., \& Ramsay, A. (2003). Earnings and impression management in financial reports: the case of CEO changes. Abacus, 39(1), 95-123.

Grote, G. (2015). Promoting safety by increasing uncertainty. Implications for risk management. Safety Science, 71, 71-79.

Grove, H., \& Clouse, M. (2016). Strategic risk management for enhanced corporate governance. Corporate Ownership \& Control, 13 (4-1), 173-182.

Güner, A. B., Malmendier, U., \& Tate, G. (2008). Financial expertise of directors. Journal of financial Economics, 88(2), 323-354.

Harner, M. M. (2010). Ignoring the writing on the wall: the role of Enterprise risk management in the economic crisis. J. Bus. \& Tech. L., 5, 45.

Harris, M., \& Raviv, A. (2008). Corporate control contests and capital structure. Journal of financial Economics, 20, 55-86.

Hentschel, L., \& Kothari, S. P. (2001). Are corporations reducing or taking risks with derivatives? Journal of financial and quantitative analysis, 36(1), 93-118.

Hilb, M. (2005). New corporate governance: from good guidelines to great practice. Corporate governance: an international review, 13(5), 569-581.

Hillman, A. J., \& Dalziel, T. (2003). Boards of directors and firm performance: Integrating agency and resource dependence perspectives. Academy of Management Review, 28(3), 383-396.

Ho, C. L., Lai, G. C., \& Lee, J. P. (2013). Organizational Structure, Board Composition, and Risk-Taking in the US property-casualty insurance industry. Journal of Risk and Insurance, 80(1), 169-203.

Hosmer Jr, D. W., Lemeshow, S., \& Sturdivant, R. X. (2013). Applied logistic regression 398. John Wiley \& Sons.

Jankensgård, H. (2019). Does Managerial Power Increase Selective Hedging? Evidence from the Oil and Gas Industry. Journal of Risk and Financial Management, 12(2), 71.

Jensen, M. C., \& Meckling, W. H. (1976). Theory of the firm: Managerial behavior, agency costs and ownership structure. Journal of financial economics, 3(4), 305-360.

Kintu, A., \& Ngugi, P. K. (2013). Determinants of Corporate Hedging Practices Used by Companies Listed in Nairobi Security exchange: A Case of Uchumi Supermarket. International Journal of Social Sciences and Entrepreneurship, 1(2), 383-398. 
Kirkpatrick, G. (2009). The corporate governance lessons from the financial crisis. OECD Journal: Financial Market Trends, 2009(1), 61-87.

Klein, A. (2002). Audit committee, Board of Director Characteristics and Earnings Management. Journal of accounting and economics, 33(3), 375-400.

Kohler, U., \& Kreuter, F. (2005). Data analysis using Stata. Stata press.

Krishnan, J. (2005). Audit committee quality and internal control: An empirical analysis. The accounting review, 80(2), 649-675

Laeven, L., \& Levine, R. (2009). Bank governance, regulation and risk-taking. Journal of financial economics, 93(2), 259-275.

Lechner, P., \& Gatzert, N. (2018). Determinants and value of enterprise risk management: empirical evidence from Germany. The European Journal of Finance, 24(10), 867-887.

Wellyn, K. B., \& Muller-Kahle, M. I. (2012). CEO power and risk taking: Evidence from the subprime lending industry. Corporate Governance: An International Review, 20(3), 289-307.

Livingstone, K. T., \& Ngugi, K. (2019). Determinants of Corporate Hedging Practices used by Companies Listed in Nairobi Security Exchange. International Journal of Business Management and Finance, 1(1).

Malmendier, U., Tate, G., \& Yan, J. (2011). Overconfidence and early-life experiences: the effect of managerial traits on corporate financial policies. The Journal of Finance, 66(5), 1687-1733.

Marsden, A., and A. K. Prevost, 2005, Derivatives Use, Corporate Governance, and Legislative Change: An Empirical Analysis of New Zealand Listed Companies. Journal of Business Finance \& Accounting, 32(1): 255-295.

Maruhun, E. N. S., Abdullah, W. R. W., Atan, R., \& Yusuf, S. N. S. (2018). The Effects of Corporate Governance on Enterprise Risk Management: Evidence from Malaysian Shariah-compliant Firms. International Journal of Academic Research in Business and Social Sciences, 8(1), 865-877.

Mayers, D., \& Smith Jr, C. W. (1987). Corporate insurance and the underinvestment problem. Journal of Risk and Insurance, 45-54.

McNulty, T., Florackis, C., \& Ormrod, P. (2012). Corporate Governance and Risk: A Study of Board Structure and Process. ACCA Research Report, 129.

Miccolis, J., \& Shah, S. (2000). Enterprise risk management: An analytic approach.

Minton, B. A., Taillard, J. P., \& Williamson, R. (2014). Financial Expertise of the Board, Risk-Taking, and Performance: Evidence from bank holding companies. Journal of Financial and Quantitative Analysis, 49(2), 351-380.

Mizruchi, M. S., \& Stearns, L. B. (1988). A longitudinal study of the formation of interlocking directorates. Administrative Science Quarterly, 194-210.

Murungi, C. M., Murage, K., \& Wanjau, K. (2014). Challenges facing non-financial firms in hedging financial risks using derivatives. International Journal of Social Sciences and Entrepreneurship, $1(10), 361-374$.

Nocco, B. W. and Stulz, R. M., (2006), Enterprise Risk Management: Theory and Practice, Journal of Applied Corporate Finance, 18(4): 8-20 
Osuoha, J., Samy, M., \& Osuoha, O. (2015). The Impact of Corporate Governance on Derivatives UsageEmpirical Evidence from African Non-Financial Firms. British Journal of Economics, Management \& Trade, 8(1), 19-31.

Pathan, S. (2009). Strong boards, CEO power and bank risk-taking. Journal of Banking \& Finance, 33(7), 1340-1350.

Payne, G. T., Benson, G. S., \& Finegold, D. L. (2009). Corporate board attributes, team effectiveness and financial performance. Journal of Management Studies, 46(4), 704-731.

Purnanandam, A. (2008). Financial distress and corporate risk management: Theory and evidence. Journal of Financial Economics, 87(3), 706-739.

Reddy, K., Locke, S., Scrimgeour, F., Gunasekarage, A. (2008). Corporate governance practices of small cap companies and their financial performance: an empirical study in New Zealand.Int. J. Business Governance and Ethics, 4(1), 51-78

Shiu, Y., C. F. Wang, and S. Lu, (2009) Reinsurance, Capital Structure and Profitability: Evidence from the Lloyd's Market, Journal of Risk Management, 16(1):59-88

Smith, C.W., \& Stulz, R.M. (1985). The Determinants of Firms' Hedging Policies. Journal of Finance and Quantitative Techniques, 20(4),391-405.

Soin, K., \& Collier, P. (2013). Risk and risk management in management accounting and control 82-87.

Souder, D., Simsek, Z., \& Johnson, S. G. (2012). The differing effects of agent and founder CEOs on the firm's market expansion. Strategic Management Journal, 33(1), 23-41.

Srivastav, A., \& Hagendorff, J. (2016). Corporate governance and bank risk-taking. Corporate Governance: An International Review, 24(3), 334-345.

Tai, V. W., Lai, Y. H., Yang, T. H., \& Yu, M. T. (2014). Corporate Hedging and Corporate Governance: The Role of the Board and the Audit Committee. Available at SSRN 2312199.

Tufano, P. (1996). Who manages risk? An empirical examination of risk management practices in the gold mining industry. The Journal of Finance, 51(4), 1097-1137.

Vafeas, N. (2003). Length of board tenure and outside director independence. Journal of Business Finance \& Accounting, 30(7-8), 1043-1064.

Xu, M. (2011). CEO contract horizon and investment. INSEAD Faculty and Research Working Paper Series.

Yunos Mohamed, R., Ismail, Z., \& Smith, M. (2012). Ethnicity and accounting conservatism: Malaysian evidence. Asian Review of Accounting, 20(1), 34-57.

Zahiruddin, G., \& Norlida, A. M. (2013). Enterprise risk management and value creation: Initial findings amongst non-financial public listed companies in Malaysian Bourse. Asian Economic and Financial Review, 3(7), 913-922. 